\title{
COUNT RUMFORD AND THE FOUNDING OF THE ROYAL INSTITUTION
}

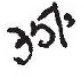

\author{
BY THOMAS MARTIN \\ General Secretary, Royal Institution
}

A HUNDRED and fifty years ago, on March 7, 1799 , a meeting was held at the house of Sir Joseph Banks in Soho Square, London, to consider proposals for founding a new scientific institution in London. The gathering in Sir Joseph's principal room or council chamber included a number of peers, members of Parliament and public men, with others distinguished for their scientific attainments or well known for their charitable and philanthropic activities. Those who had been called to the meeting were the contributors of fifty guineas each in response to an appeal "for forming by subscription, in the Metropolis of the British Empire, a Public Institution for diffusing the knowledge and facilitating the general introduction of useful mechanical inventions and improvements, and for teaching by courses of philosophical lectures and experiments the application of science to the common purposes of life".

The founders of the new institution had gone far towards ensuring the success of their enterprise by enlisting the help of Sir Joseph Banks, the allpowerful president of the Royal Society. Such was his influence in all scientific matters at this time that it is doubtful if they could have succeeded had he opposed their plan. As it was, he presided at the meeting, the proposals, which had been printed and circulated, were adopted, and it was resolved to petition His Majesty King George III for a royal charter. A committee of managers was appointed and requested "to take preparatory measures for opening the Institution". Thus by resolution of this original body of proprietors, the Royal Institution of Great Britain, as it was afterwards named in the charter, came into existence.

Sir Joseph presided at the early meetings of the managers, which were held almost weekly at this time, and the Royal Institution owes much to his sponsorship and encouragement; but for the true inspirers and originators of the project we must look in a less obvious, and somewhat unexpected, direction. Among the subscribers who attended the original meeting were William Wilberforce, Thomas Bernard and Count Rumford. Wilberforce, the member of Parliament for Yorkshire, was the great advocate of the abolition of slavery. Thomas (afterwards Sir Thomas) Bernard was the treasurer of the Foundling Hospital. Sir Benjamin Thompson, Count Rumford, was that remarkable soldier, statesman and man of science who had been horn in America and had come to England during tho War of Independence: he had recently returned to this country after a long period in high office under the Elector Palatine of Bavaria. Only one of these three, Rumford, had scientific attainments to account for his interest in the new institution : but all were actively engaged in humanitarian and philanthropic enterprises, and in particular were associated in the affairs of a society called the Society for Bettering the Condition and Increasing the Comforts of the Poor.

Rumford, whose title as a Count of the Holy Roman Empire had been conferred on him by the Elector Karl Theodor, had spent the most active and fruitful years of his career in Bavaria. It was in Munich that the greater part of his scientific work on heat had been carried out, including his wellknown experiment on the source of the heat excited in the boring of cannon at the Arsenal; but his experiments were by way of relaxation, in a life fully occupied with military and administrative duties. In these he had shown great enterprise and versatility, providing the firm hand which was sorely needed by the Elector in the government of his country. Bavaria was suffering from the ravages of war, there was corruption in high places and poverty and lawlessness among the people. Gangs of beggars and vagabonds, many of them ex-soldiers, roamed the country, converging on Munich, where they systematically extorted alms from the more law-abiding citizens.

The state of affairs had become intolerable, and after much consideration Rumford devised a plan, which with the aid of the military he put into operation on New Year's Day, 1790, for arresting all the beggars in the city. The able-bodied were put to useful work in 'houses of industry' and the infirm given alms from funds subscribed by the citizens. Thereafter begging was prohibited. By his humane and enlightened methods with the poor people and his care in the administration of his "institutions for the poor', Rumford succeeded in making his system work and in ridding Munich of its incubus for a considerable period of years.

$\mathrm{He}$ became much interested in the problems of practical philanthropy, and devoted attention to such matters as economy of fuel, the design of stoves and fireplaces, the improvement of cooking utensils and the preparation of nourishing food at a minimum of cost. The fame of his methods spread to other countries, and he was consulted everywhere on the economy of establishments for the poor. 'Rumford soup kitchens' and 'eating houses' were set up in many places. In London he advised on the arrangements at the Foundling Hospital. Its treasurer, Thomas Bernard, was a particular admirer of his methods, and in 1796 proposed the formation of a society to promote their introduction into Britain. The society thus established, with the active co. operation of Wilberforce and other philanthropists, was the 'Bettering' Society mentioned above.

It was naturally with his friends in the Bettering Society that Rumford discussed a particularly cherished scheme, that of an institution to be devoted to the application of science and invention to the improvement of the lot of the poorer classes; and early in 1799 the Society launched the appeal which, as we have seen, resulted in the formation of the Royal Institution. The Bettering Society was thus the precursor of the Institution; but Rumford early decided that this new establishment was too interesting and important to be merely an appendage of another society. In the proposals, therefore, which he drew up himself, and in which its objects were described in great detail, it was given a separate constitution; and as he worked on the scheme its magnitude and its possibilities grew in his eyes. Before long the house in Albemarle Street, which the Institution still occupies, was purchased; and the royal charter was duly granted by the King. At the request of the managers, Rumford went to live at 


\section{COUNT RUMFORD AND THE FOUNDING OF THE ROYAL INSTITUTION}

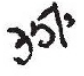

\author{
BY THOMAS MARTIN \\ General Secretary, Royal Institution
}

A HUNDRED and fifty years ago, on March 7, 1799 , a meeting was held at the house of Sir Joseph Banks in Soho Square, London, to consider proposals for founding a new scientific institution in London. The gathering in Sir Joseph's principal room or council chamber included a number of peers, members of Parliament and public men, with others distinguished for their scientific attainments or well known for their charitable and philanthropic activities. Those who had been called to the meeting were the contributors of fifty guineas each in response to an appeal "for forming by subscription, in the Metropolis of the British Empire, a Public Institution for diffusing the knowledge and facilitating the general introduction of useful mechanical inventions and improvements, and for teaching by courses of philosophical lectures and experiments the application of science to the common purposes of life".

The founders of the new institution had gone far towards ensuring the success of their enterprise by enlisting the help of Sir Joseph Banks, the allpowerful president of the Royal Society. Such was his influence in all scientific matters at this time that it is doubtful if they could have succeeded had he opposed their plan. As it was, he presided at the meeting, the proposals, which had been printed and circulated, were adopted, and it was resolved to petition His Majesty King George III for a royal charter. A committee of managers was appointed and requested "to take preparatory measures for opening the Institution". Thus by resolution of this original body of proprietors, the Royal Institution of Great Britain, as it was afterwards named in the charter, came into existence.

Sir Joseph presided at the early meetings of the managers, which were held almost weekly at this time, and the Royal Institution owes much to his sponsorship and encouragement; but for the true inspirers and originators of the project we must look in a less obvious, and somewhat unexpected, direction. Among the subscribers who attended the original meeting were William Wilberforce, Thomas Bernard and Count Rumford. Wilberforce, the member of Parliament for Yorkshire, was the great advocate of the abolition of slavery. Thomas (afterwards Sir Thomas) Bernard was the treasurer of the Foundling Hospital. Sir Benjamin Thompson, Count Rumford, was that remarkable soldier, statesman and man of science who had been horn in America and had come to England during tho War of Independence: he had recently returned to this country after a long period in high office under the Elector Palatine of Bavaria. Only one of these three, Rumford, had scientific attainments to account for his interest in the new institution : but all were actively engaged in humanitarian and philanthropic enterprises, and in particular were associated in the affairs of a society called the Society for Bettering the Condition and Increasing the Comforts of the Poor.

Rumford, whose title as a Count of the Holy Roman Empire had been conferred on him by the Elector Karl Theodor, had spent the most active and fruitful years of his career in Bavaria. It was in Munich that the greater part of his scientific work on heat had been carried out, including his wellknown experiment on the source of the heat excited in the boring of cannon at the Arsenal; but his experiments were by way of relaxation, in a life fully occupied with military and administrative duties. In these he had shown great enterprise and versatility, providing the firm hand which was sorely needed by the Elector in the government of his country. Bavaria was suffering from the ravages of war, there was corruption in high places and poverty and lawlessness among the people. Gangs of beggars and vagabonds, many of them ex-soldiers, roamed the country, converging on Munich, where they systematically extorted alms from the more law-abiding citizens.

The state of affairs had become intolerable, and after much consideration Rumford devised a plan, which with the aid of the military he put into operation on New Year's Day, 1790, for arresting all the beggars in the city. The able-bodied were put to useful work in 'houses of industry' and the infirm given alms from funds subscribed by the citizens. Thereafter begging was prohibited. By his humane and enlightened methods with the poor people and his care in the administration of his "institutions for the poor', Rumford succeeded in making his system work and in ridding Munich of its incubus for a considerable period of years.

$\mathrm{He}$ became much interested in the problems of practical philanthropy, and devoted attention to such matters as economy of fuel, the design of stoves and fireplaces, the improvement of cooking utensils and the preparation of nourishing food at a minimum of cost. The fame of his methods spread to other countries, and he was consulted everywhere on the economy of establishments for the poor. 'Rumford soup kitchens' and 'eating houses' were set up in many places. In London he advised on the arrangements at the Foundling Hospital. Its treasurer, Thomas Bernard, was a particular admirer of his methods, and in 1796 proposed the formation of a society to promote their introduction into Britain. The society thus established, with the active co. operation of Wilberforce and other philanthropists, was the 'Bettering' Society mentioned above.

It was naturally with his friends in the Bettering Society that Rumford discussed a particularly cherished scheme, that of an institution to be devoted to the application of science and invention to the improvement of the lot of the poorer classes; and early in 1799 the Society launched the appeal which, as we have seen, resulted in the formation of the Royal Institution. The Bettering Society was thus the precursor of the Institution; but Rumford early decided that this new establishment was too interesting and important to be merely an appendage of another society. In the proposals, therefore, which he drew up himself, and in which its objects were described in great detail, it was given a separate constitution; and as he worked on the scheme its magnitude and its possibilities grew in his eyes. Before long the house in Albemarle Street, which the Institution still occupies, was purchased; and the royal charter was duly granted by the King. At the request of the managers, Rumford went to live at 
the house, so that he could personally supervise every detail of the arrangements, and for two years this became his principal occupation.

A special feature of the Institution was to be the Repository or Model-room in which working models of new inventions were to be exhibited. There were to be fireplaces, stoves and kitchen utensils of the latest design. A complete kitchen was to be equipped, from which meals would be served to the proprietors. Workshops would be established and classes held for the instruction of artisans and mechanics. The speedy introduction of all useful mechanical inventions and improvements was to be one of the two principal objects ; the other was the application of science to the improvement of arts and manufactures, and for this purpose a lecture room and laboratories would be provided, professors and lecturers engaged, courses of philosophical lectures would be given and chemical and other experiments carried out. For the management of the Institution there were to be committees of managers to govern and direct, and 'visitors' to inspect and audit, responsible to the proprietors, whose interest was hereditary.

For a time the efforts of the early managers met with much success. The ninth Earl of Winchilsea became the first president; the nobility and gentry, the philanthropic and the learned, gave their support as proprietors or subscribers. The lecture theatre, now famous as one of the best for its purpose in existence, was built, the model room, laboratories and workshops constructed and equipped, and the library and reading-rooms opened to the proprietors. Dr. Thomas Garnett, from Anderson's Institution in Glasgow, was engaged as the first professor, and courses of lectures were begun.

This was the Royal Institution as it was originally conceived, and although there have been great changes, those who know it will recognize much that has survived to the present day. It was Rumford's plan, and in the early years his ideas were closely followed. $\mathrm{He}$ is rightly regarded as the founder; although by some a share at least of the honours has been claimed for Sir Thomas Bernard.

After a time, however, differences of opinion arose. Rumford quarrelled with Prof. Garnett, and he fell out with some of the other managers, who found him dictatorial and overbearing. Not all of them were in sympathy with his philanthropic ideas or believed that the poor and the working classes in Britain would respond to the methods he had found successful in Bavaria. Moreover, the plan for the Institution proved too ambitious and expensive and had to be curtailed. Rumford began to lose interest; he went off to the Continent again, intending to return; but, in fact, he stayed in Paris to marry the widow of the great French chemist Lavoisier.

The control of the Royal Institution fell into other hands. The new managers quietly dropped the classes for mechanics, the cooking and kitchen economy, and other features of Rumford's plan, and endeavoured to popularize the establishment with those to whom it looked for financial support by arranging courses of lectures on popular science, literature and the arts. Sir Joseph Banks in London grumbled by letter to Rumford regretting his absence. telling him that the Institution was "now entirely in the hands of the profane" and declaring that he would have nothing more to do with it.

But the changes which now took place were due not so much to acts of the management as to the activities and growing reputation of Humphry Davy.
Before he left England, Rumford had engaged this young man from Bristol as lecturer in chemistry. Thomas Young had succeeded Garnett, and for a time Young and Davy worked together. Later, Davy became the professor of chemistry, and it is well known how his gifts as a lecturer and his brilliant researches on the chemical action of electricity established both his own reputation and that of the Institution. Scientific research and exposition became the order of the day.

This alteration of purpose was frankly recognized by an Act of Parliament in 1810, which amended the constitution of the Institution, extending its objects to include the "promotion of chemical science by experiments and lectures" and the "diffusion and extension of useful knowledge in general", and substituting for the hereditary proprietors, who were compensated and dispossessed, a body of elected members. Constitutionally, the Royal Institution as we know it to-day dates from the Act of 1810 ; but its character and traditions were established by the brilliance of Humphry Davy, to be maintained and enlarged by the genius of his assistant and successor, Michael Faraday.

At this hundred and fiftieth anniversary, however, we celebrate the founder, Benjamin Thompson, Count Rumford. He made probably his greatest contribution to its success when he brought Humphry Davy to work in his Institution; and if it is some. thing of a changeling from the establishment he originally intended, none will now deny him credit for the importance of his achievement or its significance in the history of science.

\section{FOREST RESOURCES OF THE WORLD}

A SMALL booklet has recently been issued by the A Food and Agriculture Organisation of the United Nations, Diffigion of Forestry, entitled "Forest Resources of \&1g world" (Washington, D.C., 1948). This repon is of first importance and interest, and discloses the steps which have been taken to have a regl in teftory of the world's forestry resources pffifred, a piece of work far more difficult of afliefement than might be supposed. This difficulty is due to the fact that a considerable proportion of the forests of the world are still without any really proper and efficient management. Consequently, any figures obtained on the subject of the abundance or otherwise of their several resources can, in certain cases, be accepted only with reserve.

The report commences with the question as to whether or not man will be compelled to resign himself to a perpetual shortage of forestry products. To this the report's answer is 'No', and this reply applies to a still larger population than at present exists. It will be of interest to follow the argument which, of necessity, must be based to a considerable extent on the still untapped forests of the world.

From earliest times a large section of the world's population has depended on the forest-at first for fuel only, then for timber for house construction, farm implements and so forth. The introduction of more modern forms of building, it was said, would see the importance of timber decrease and, therefore, the people's corresponding dependence on the forest. The reverse has been the case. The modern industrial age has brought with it new demands on wood for direct use in manufacturing industries and for 